\title{
DIETARY INTAKE OF MINERALS IN DIETS OF ADULTS PREPARING FOR MARATHON
}

\author{
Agnieszka Salomon, 1, B, C, D Anna Mandecka,, B, D Dorota Różańska,, B, C, D \\ Klaudia Konikowska, ${ }^{1, B, D}$ Aureliusz Kosendiak², A, E Bożena Regulska-Ilow ${ }^{1, D, E}$ \\ ${ }^{1}$ Wroclaw Medical University, Department of Dietetics, Poland \\ 2 Wroclaw Medical University, Department of Organization and Management, Poland \\ A Study Design; ${ }^{B}$ Data Collection; ${ }^{C}$ Statistical Analysis; ${ }^{D}$ Manuscript Preparation; ${ }^{~}$ Funds Collection
}

\author{
Address for corpespondence: \\ Anna Mandecka \\ Department of Dietetics, Wrocław Medical University \\ Parkowa 34, 51-616 Wroclaw, Poland \\ E-mail: anna.mandecka@umed.wroc.pl
}

\begin{abstract}
Ahstract The aim of the study was to evaluate the mineral content in the diets of amateurs preparing for a marathon. The examined group consisted of 92 women (W), whose average age was $30.8 \pm 6.7$ years and 66 men $(M)$, whose average age was $33.2 \pm 6.6$ years. The evaluation of the mineral content of the diets of the surveyed people was done using three-day dietary records which included one day of the weekend. The average daily sodium content in the diets of women was $1,952.2 \pm 729.2 \mathrm{mg}$, and in the diets of men it was $3,093.1 \pm 1,063.3 \mathrm{mg}$ whereas potassium content was $3,361.6 \pm 798.5 \mathrm{mg}$ and $3,900.3 \pm 982.3 \mathrm{mg}$ respectively. The potassium content of less than $90 \%$ of fulfilling the norm was observed in the diets of $84.8 \%$ of women and $66.7 \%$ of men. The average content of calcium in the diets of women and men amounted to $887.5 \pm 278.8 \mathrm{mg}$ and $1,162.6 \pm 434.3 \mathrm{mg} /$ day respectively. The diets of $30.4 \%$ of women and $16.7 \%$ of men had insufficient calcium content as compared to the norms. The average daily phosphorus and magnesium content was significantly higher in men than in women $(1,374.6 \pm 348.6 \mathrm{vs} 1,823.5 \pm 473.0 \mathrm{mg}$ and $373.4 \pm 107.1 \mathrm{vs} 423.6 \pm 108.8 \mathrm{mg})$. Magnesium intake was insufficient in the diets of $14.1 \%$ of women and $28.8 \%$ of men. The average daily content of iron, zinc and copper in the group of women was: $12.1 \mathrm{mg}, 10.1 \mathrm{mg}$ and $1.4 \mathrm{mg}$, while in the diets of men respectively $14.8 \mathrm{mg}, 13.5 \mathrm{mg}$ and $1.5 \mathrm{mg}$. The highest percentage of diets not fulfilling the norm was found for calcium and potassium in women, and potassium and magnesium for men.
\end{abstract}

Key worlds marathon, minerals, micronutrients, macronutrients

\section{Introduction}

In recent years, running has become a very popular form of physical activity, as evidenced by the growing number of amateurs competing in marathons and half-marathons. Training in preparation for a marathon is similar to the structure of long-distance runs that best prepare for long-term physical exertion (Dzięgiel, Lubowiecki-Vikuk, 2013; Skrzypczak, Jarecka, Fak, 2014). When preparing for a marathon, the whole functioning of the body is subject adaptation, especially cardiovascular, nervous and respiratory systems (Celejowa, 2008). Among those taking part 
in the marathon, there is great interest in ways that would help to achieve the maximum efficiency of the body during prolonged exercise. One of them is the use of a properly balanced diet, which may significantly affect the sports results obtained and support the regeneration process after exercise (Figurska-Ciura, Bartnik, Bronkowska, Biernat, 2014).

The diet of physically active people during training should take into account not only the increased demand for energy and ingredients such as carbohydrates, proteins and fats, but also consider vitamins and minerals which act as the regulatory and building blocks (Żbikowski, Lebiedzińska, Czaja, 2007). The following minerals may be mentioned among the most important minerals in the diet of the athlete: calcium, phosphorus, magnesium, sodium, potassium, iron, zinc and copper. Deficiencies of vitamins and minerals in athletes results in a reduced ability to exercise. Due to irregular eating or restricting the use of certain products, many athletes consume an insufficient amount of vitamins and minerals. Training also increases the demand for these components because of the accelerated metabolism and losses associated with the loss incurred through sweat and urine (Matwiejuk, 2009; Szczepańska, Malczewska, 2003). Supplementing these minerals in their diet thus becomes a necessity. Increased food intake in order to cover the energy needs should also protect the athletes in terms of supply of dietary minerals (Maughan, 1999).

The aim of the study was to evaluate the mineral content in the diets of amateurs preparing for a marathon.

\section{Material and methods}

The study group consisted of 158 people (92 women and 66 men) who were preparing to participate in the Wroclaw marathon in 2012 and 2013. The average age of women and men was $30.8 \pm 6.7$ and $33.2 \pm 6.6$ years respectively. All subjects participated in the program entitled "I Ty możesz zostać maratończykiem". Running classes lasted half a year, and their aim was to prepare the participants in the program to complete a marathon. During the preparatory period the marathoners took part in 2 organized practise sessions per week for a total average distance of $25-35 \mathrm{~km}$. Additionally, they had to do 2 workouts individually in their spare time, according to the trainer's recommendations.

The subjects had their height, weight, waist and hip circumferences measured and their Body Mass Index (BMI) was calculated.

Dietary data were collected in the preparatory period before the marathon in May and June in 2012 and 2013. The evaluation of the mineral content in the diets of people participating in the study carried out by the 3-days dietary record with the following days: one day of training, one day without training and one day of the weekend. Study participants wrote down consumed food products using household measurements (eg. a spoon, plate, cup), and then trained surveyors clarified the of mass food intake using the "Album of photographs of food products and dishes" (Szponar, Wolnicka, Rychlik, 2000). The analysis of daily food rations in terms of mineral content were performed the computer program "Food Processor SQL" containing a Polish database developed by Kunachowicz et al. (2005).

For each of the subjects, an average content of minerals such as sodium, potassium, calcium, phosphorus, magnesium, iron, zinc and copper in diet was calculated and compared it with the standards of nutrition for the Polish population at the level of Estimated Average Requirement (EAR) or Adequate Intake (Al), taking into account the age and gender of the subjects (Jarosz, 2012). The average fulfilment of norms of minerals and the proportion 
of people whose diets did not meet the norms were evaluated. The proportion of diet, which fulfilled the norms for minerals within the following ranges: $<90 \%, 91-110 \%, 111-150 \%, 151-200 \%,>200 \%$ were also evaluated.

A statistical analysis was performed using the software STATISTICA 10 from StatSoft, Inc. USA. Comparison of the mineral content in the diets of men and women were performed using non-parametric $U$ Mann Whitney test, and categorical variables using the $\mathrm{Chi}^{2}$ test. $\mathrm{P}$ value $<0.05$ was assumed as the level of significance.

\section{Results}

Table 1 shows the characteristics of the study group of women and men. Average BMI indicated that studied women were characterized by normal weight, while in men the average value was in the overweight range.

Table 1. Anthropometric characteristics of surveyed women and men

\begin{tabular}{lccc}
\hline \multirow{2}{*}{ Parameter } & Unit & Women $(\mathrm{n}=92)$ & Men $(\mathrm{n}=66)$ \\
\cline { 3 - 4 } & & $\mathrm{X} \pm \mathrm{SD}$ & $\mathrm{X} \pm \mathrm{SD}$ \\
\hline Age & years & $30.8 \pm 6.7$ & $33.2 \pm 6.6$ \\
Height & $\mathrm{cm}$ & $166.0 \pm 6.1$ & $178.9 \pm 7.1$ \\
Weight & $\mathrm{kg}$ & $61.8 \pm 9.1$ & $81.2 \pm 11.9$ \\
BMl & $\mathrm{kg} / \mathrm{m}^{2}$ & $22.4 \pm 2.7$ & $25.3 \pm 2.8$ \\
\hline
\end{tabular}

$\mathrm{X}$ - mean, SD - standard deviation, $\mathrm{n}$ - number of people surveyed.

The study evaluated daily food rations (DFR) in terms of the content of mineral components such as sodium, potassium, calcium, phosphorus, magnesium, iron, zinc and copper, and the results are shown in Tables 2 and 3. The average intake of all dietary minerals with the exception of copper was statistically significantly higher in a group of men compared to the group of women (Table 2). Daily food rations for men and women, with an average energy value of $1,982.3 \pm 506.5$ and $2,808.1 \pm 731.6 \mathrm{kcal} /$ day respectively $(p<0.05)$, covered the needs of the majority of the study group to evaluated minerals, with the exception of potassium. It was found that diets of $93 \%$ of women and $80 \%$ of men did not cover the demand for this mineral.

Tahle 2. Average daily intake of dietary minerals in a group of men and women preparing for a marathon, and norms for selected minerals by gender and age of the respondents

\begin{tabular}{|c|c|c|c|c|c|c|}
\hline \multirow{2}{*}{ Minerals } & \multirow{2}{*}{ Unit } & \multicolumn{2}{|c|}{ Women $(W) n=92$} & \multicolumn{2}{|c|}{ Men $(M) n=66$} & \multirow{2}{*}{$\begin{array}{c}\text { W vs } M \\
p\end{array}$} \\
\hline & & norms & $X \pm S D$ & norms & $X \pm S D$ & \\
\hline Sodium & $\mathrm{mg}$ & $1,500^{* *}$ & $1,952.2 \pm 729.2$ & $1,500^{* *}$ & $3,093.1 \pm 1,063.3$ & $<0.000$ \\
\hline Potassium & $\mathrm{mg}$ & $4,700^{\star *}$ & $3,361.6 \pm 798.5$ & $4,700^{\star *}$ & $3,900.3 \pm 982.3$ & 0.001 \\
\hline Calcium & $\mathrm{mg}$ & $800^{*}$ & $887.5 \pm 278.8$ & $800^{*}$ & $1,162.6 \pm 434.3$ & $<0.000$ \\
\hline Phosphorus & $\mathrm{mg}$ & $580^{*}$ & $1,374.6 \pm 348.6$ & $580^{*}$ & $1,823.5 \pm 473.0$ & $<0.000$ \\
\hline Magnesium & $\mathrm{mg}$ & $255^{a}-265^{b}$ & $373.4 \pm 107.1$ & $330^{\mathrm{a}}-350^{\mathrm{b}}$ & $423.6 \pm 108.8$ & 0.014 \\
\hline Iron & $\mathrm{mg}$ & $8^{*}$ & $12.1 \pm 3.5$ & $6^{*}$ & $14.8 \pm 4.7$ & $<0.000$ \\
\hline Zinc & $\mathrm{mg}$ & $6.8^{*}$ & $10.1 \pm 2.6$ & $9.4^{*}$ & $13.5 \pm 3.8$ & $<0.000$ \\
\hline Copper & $\mathrm{mg}$ & $0.7^{*}$ & $1.4 \pm 0.5$ & $0.7^{*}$ & $1.5 \pm 0.4$ & 0.079 \\
\hline
\end{tabular}

${ }^{*}$ EAR - Estimated Average Requirement, ${ }^{* *} \mathrm{Al}$-Adequate Intake, ${ }^{\mathrm{a}}$ - EAR in the $19-30$ years age group,${ }^{\mathrm{b}}-\mathrm{EAR}$ in the $31-50$ years age group, $\mathrm{X}-\mathrm{mean}, \mathrm{SD}-\mathrm{standard}$ deviation, $p<0.05-$ statistically significant. 
Table 3. The average fulfilment of norms for selected minerals and comparison of the proportion of the diets in a group of women and men who have not met the norm on selected minerals

\begin{tabular}{|c|c|c|c|c|c|}
\hline \multirow[b]{2}{*}{ Minerals } & \multicolumn{2}{|c|}{ Women $(W) n=92$} & \multicolumn{2}{|c|}{$\operatorname{Men}(M) n=66$} & \multirow{2}{*}{$\begin{array}{l}\text { W vs } M \\
{ }^{*} p<0.05\end{array}$} \\
\hline & $\begin{array}{l}\text { percent fulfilment of norms } \\
\qquad X \pm S D\end{array}$ & $\begin{array}{l}\text { percent of diets lower } \\
\text { than the norm }\end{array}$ & $\begin{array}{l}\text { percent fulfilment of norms } \\
\qquad X \pm S D\end{array}$ & $\begin{array}{l}\text { percent of diets } \\
\text { lower than the norm }\end{array}$ & \\
\hline Sodium & $130.1 \pm 48.6$ & 26.1 & $206.2 \pm 70.9$ & 3.0 & 0.0001 \\
\hline Potassium & $71.5 \pm 17.0$ & 93.5 & $83.0 \pm 20.9$ & 80.3 & 0.0120 \\
\hline Calcium & $110.9 \pm 34.8$ & 44.6 & $145.3 \pm 54.3$ & 19.7 & 0.0012 \\
\hline Phosphorus & $237.0 \pm 60.1$ & 0.0 & $314.4 \pm 81.6$ & 0.0 & - \\
\hline Magnesium & $143.9 \pm 41.7$ & 14.1 & $124.2 \pm 32.3$ & 30.3 & 0.0137 \\
\hline Iron & $151.1 \pm 43.2$ & 8.7 & $247.4 \pm 78.2$ & 0.0 & 0.0366 \\
\hline Zinc & $147.9 \pm 38.8$ & 10.9 & $143.5 \pm 40.1$ & 12.1 & 0.8071 \\
\hline Copper & $203.7 \pm 67.6$ & 1.1 & $217.0 \pm 56.3$ & 0.0 & 0.8671 \\
\hline
\end{tabular}

$\mathrm{X}$ - mean, SD - standard deviation, ${ }^{*} \mathrm{p}$ value for differences in the amount of diets lower than the norm between men and women.

The average intake of sodium with the diet was 1,952.2 $\pm 729.2 \mathrm{mg} /$ day in the group of women and 3,093.1 $\pm 1063.3 \mathrm{mg} /$ day in the group of men, which was $130.1 \%$ and $206.2 \%$ of the norm. The study did not take into consideration the salt added to foods during their preparation.

The average intake of calcium in the diets of women surveyed was $887.5 \pm 278.8 \mathrm{mg}$ and $1,162.6 \pm 434.3 \mathrm{mg}$ in the group of men, which represented $110.9 \%$ and $145.3 \%$ fulfilment of the norms. At the same time, it was observed that the diets of $44.6 \%$ of women and $19.7 \%$ of men did not cover the daily requirement for calcium.

The average intake of phosphorus in the DFR for women and men preparing for a marathon exceeded the norm and was as follows: $1,374.6 \pm 348.6 \mathrm{mg} /$ day $(237.0 \%$ of the norm) and $1,823.5 \pm 473.0 \mathrm{mg} / \mathrm{day}$ ( $314.4 \%$ of the norm). In the diets of approximately $70 \%$ of women and $86 \%$ men, phosphorus intake exceeded $200 \%$ of the norm (Table 4). In the diets of men as well as in the diets of women an abnormal ratio of calcium to phosphorus amounting $0.7: 1$ and $0.63: 1$, was noted, although the preferred ration is $1: 1$.

Table 4. Percentage of diets of surveyed women (W) and men (M), which fulfilled the norm for selected minerals at the following levels $<90 \%, 91-110 \%, 111-150 \%, 151-200 \%$ and $>200 \%$

\begin{tabular}{|c|c|c|c|c|c|c|c|c|c|c|c|c|c|c|c|c|}
\hline \multirow{2}{*}{$\begin{array}{c}\% \text { fulfilment } \\
\text { of norms }\end{array}$} & \multicolumn{2}{|c|}{ Sodium } & \multicolumn{2}{|c|}{ Potassium } & \multicolumn{2}{|c|}{ Calcium } & \multicolumn{2}{|c|}{ Phosphorus } & \multicolumn{2}{|c|}{ Magnesium } & \multicolumn{2}{|c|}{ Iron } & \multicolumn{2}{|c|}{ Zinc } & \multicolumn{2}{|c|}{ Copper } \\
\hline & W & $M$ & W & $M$ & $W$ & $M$ & W & $M$ & W & $M$ & W & $M$ & W & M & W & $M$ \\
\hline$<90$ & 19.6 & 3.0 & 84.8 & 66.7 & 30.4 & 16.7 & 0.0 & 0.0 & 14.1 & 28.8 & 2.2 & 0.0 & 6.5 & 7.6 & 0.0 & 0.0 \\
\hline $91-110$ & 15.2 & 3.0 & 15.2 & 22.7 & 25.0 & 10.6 & 0.0 & 0.0 & 18.5 & 18.2 & 12.0 & 0.0 & 10.9 & 16.6 & 3.3 & 0.0 \\
\hline $111-150$ & 38.0 & 15.2 & 0.0 & 10.6 & 30.4 & 28.8 & 4.3 & 0.0 & 42.4 & 37.9 & 45.7 & 9.1 & 35.9 & 39.4 & 17.4 & 12.1 \\
\hline $151-200$ & 18.5 & 33.3 & 0.0 & 0.0 & 14.2 & 27.3 & 25.0 & 13.6 & 17.4 & 13.6 & 26.1 & 21.2 & 38.0 & 28.8 & 35.8 & 34.8 \\
\hline$>200$ & 8.7 & 45.5 & 0.0 & 0.0 & 0.0 & 16.6 & 70.7 & 86.4 & 7.6 & 1.5 & 14.0 & 69.7 & 8.7 & 7.6 & 43.5 & 53.1 \\
\hline
\end{tabular}

The average intake of magnesium in DFR for women was $373.4 \pm 107.1 \mathrm{mg} /$ day ( $143.9 \%$ of the norm), and a group of men $423.6 \pm 108.8 \mathrm{mg} / \mathrm{day}$ (124.2\% of the norm). It was observed that, a high percentage of women and men's diets did not provide optimal amounts of magnesium. Magnesium intake below the norm pertained to $14.1 \%$ of women and $30.3 \%$ men. 
The average percentage of fulfilment of the norm for iron in the diets of women was $151.1 \%$ ( $12.1 \pm 3.5 \mathrm{mg} /$ day), and $247.4 \%$ in the diets of men ( $14.8 \pm 4.7 \mathrm{mg} /$ day). Supply of iron below the norm was observed in $8.7 \%$ of women. Furthermore it was found that $69 \%$ of the diets of men exceeded the supply of iron standard twice over (Table 4).

The average intake of zinc in the DFR of the surveyed people covered daily requirement and averaged 10.1 $\pm 2.6 \mathrm{mg} /$ day for women and $13.5 \pm 3.8 \mathrm{mg} /$ day for men. At the same time, it was found that about $10 \%$ of the diets of women and $12 \%$ of the diets of men did not fulfil this trace mineral norm. The average supply of copper in DFR was $1.4 \pm 0.5 \mathrm{mg} /$ day in the group of women and $1.5 \pm 0.4 \mathrm{mg} /$ day in the group of men, which in both groups exceeded the norm more than twice (Table 4).

It has been shown that the percentage of women whose diets did not cover the demand for sodium, potassium, calcium, and iron was statistically significantly higher compared to men (Table 3). On the other hand there was a statistically significantly higher proportion of men whose diets do not fulfil the standards for magnesium than women.

\section{Discussion}

The study shows that the daily food rations for both women and men preparing for a marathon were characterized by insufficient content of some minerals, especially potassium, calcium and magnesium.

The average energy value of DFR of the surveyed population for both women and men was lower than the energy demand of people of moderate physical activity (Jarosz et al., 2012). Wierniuk and Włodarek (2013) have also shown that DFR of aerobic sports-training men has too low energy value (average of 2,466 $\pm 591 \mathrm{kcal} /$ day with an average demand of $3,331 \pm 252 \mathrm{kcal} / \mathrm{day}$ ). Similar results were obtained by Włodarek et al. (2011), who evaluated the implementation of energy demand in long-distance runners. The average energy value of the diet was $3,030 \pm 520 \mathrm{kcal}$ for men and 2,100 $\pm 700 \mathrm{kcal}$ for women. Insufficient energy values of the diet, lasting for a long time, particularly among individuals with increased physical activity can affect the insufficient supply of nutrients, including the micro- and macronutrients.

Increased supply of minerals in the diet of sportsmen and amateurs may be necessary due to the increased loss in sweat and urine (Lombardi et al., 2013). With respect to individual components, the greatest threat to people taking part in regular physical activity is due to the low supply of dietary iron and calcium (Matwiejuk, 2009; Seidler, Gryza, 2006). Iron is a mineral which deficiency in the body significantly reduces performance during exercise. Iron is the main component necessary for the construction of myoglobin and haemoglobin involved in the transport of oxygen from the lungs to the tissues (Lombardi et al., 2013; Matwiejuk, 2009). Iron is one of the minerals that intake with diet of physically active people is too low (Lombardi et al., 2013; Seidler, Gryza, 2006). The purpose of the study conducted by Merritt (2013) was to determine the dietary iron consumption of female recreational marathon runners. In this study mean iron intake by all participants was lower than that of Recommended Dietary Allowance (RDA). The deficiencies of iron are caused mainly by low intake of meat products and its limited bioavailability from plant products. Iron deficiencies are more common for young sportswomen because of its losses associated with menstruation (Burblis et al., 2014; Christensen et al., 2005; Lukaski, 2004). Furthermore the runners are exposed to erythrocyte haemolysis as a result of mechanical damage of small blood vessels in the lower limbs. Christensen et al. (2005) estimated the supply of some minerals in the diet of Kenyan medium- and long-distance runners. An unusual feature of the diet of Kenyans was very high iron content from an average of 124-178 mg. The main source of iron in their diet were plant products such as maize and beans, which have a low bioavailability of that mineral. 
In our study, it was noticed that $8.7 \%$ of the diets of women do not fulfil the standards of the EAR for this nutrient. The results obtained indicate the need to supplement the diet of women in iron, which can be obtained through the consumption of at least one meat meal a day. Among the iron sources with the greatest bioavailability the following products may be mentioned: liver (7.5-18.7 mg/100 g), beef (1.3-3.1 mg/100 g), poultry (1.2-2.4 mg/100 g), sardines $(2.9 \mathrm{mg} / 100 \mathrm{~g})$, hen's egg yolk $(7.2 \mathrm{mg} / 100 \mathrm{~g})$ (Kunachowicz et al., 2005). Bioavailability of iron from vegetable products is greatly increased by the dietary components such as vitamin C, fructo-oligosaccharides or resistant starch. Many sportsmen use supplementation to compensate for the iron deficiencies (Alaunyte et al., 2015; Nieves et al., 2002). It should be noted, however, that uncontrolled iron supplementation especially for amateur sportsmen is inadvisable. It has been proven, that excessive intake of iron preparations, reduces the concentration of other minerals such as zinc and lead thus increasing production of free radicals and the risk of cancer and heart disease (Gennari, 2001; Lukaski, 2004; Nieves et al., 2002).

Physical activity is one of the key elements that affect bone mineralization and achieve peak bone mass. Exercise slows down the rate of bone mass loss with age, preventing osteoporosis (Banfi et al., 2010; Zimmermann, 2003). In some sporting disciplines, including long-distance running, very often an insufficient supply of energy and certain nutrients including calcium is found (Lombardi et al., 2013; Maughan, 1999; Zimmermann, 2003). Womenathletes who have low oestrogen levels which is also a risk factor for accelerated bone loss are particularly at risk of osteoporosis (Maughan, 1999; Williams, 2005). Adequate intake of dietary calcium appears to be a key factor in the prevention of osteoporosis, since $99 \%$ of the calcium in the body is around the skeletal system. Calcium is involved in many physiological processes associated with muscle contraction. In addition, high-intensity exercise increases the loss in sweat (Zimmermann, 2003). Demand for calcium in athletes is estimated at about $1200 \mathrm{mg} /$ day (Celejowa, 2008). Both in our study and in studies of other authors (Lombardi et al., 2013; Lukaski, 2004; Onywera et al., 2004; Seidler, Gryza, 2006) there was a particularly high proportion of women who did not meet the norm for this mineral. Christensen et al. (2005) showed that calcium intake from diets of elite runners from Kenya, was also very low (577-655 mg/day). These studies, however, suggest that high physical activity can have a more determining role in the development and maintenance of normal bone mass than high calcium intake with the diet. Simultaneously, other studies have shown a positive association with increased calcium intake from the diet with improved bone density and reduction of fractures in runners (Myburgh, 1999; Nieves et al., 2002). Myburgh et al. (1999) conducted a clinical-control study which evaluated the risk of stress fractures in long-distance runners, depending on the content of calcium in their diet. It was found that in the group of people with fractures dietary calcium intake was lower than in the control group. This group also had significantly lower bone mineral density at the lumbar spine and femoral neck, compared with the control group. Nieves et al. (2002) also studied bone density and frequency of fractures in young runners, to whom a daily intake of additional servings of skimmed milk was recommended. Higher calcium intake with the diet in the form of dairy products and milk positively correlated with a reduction in the incidence of fractures. The risk of fractures in the study group was reduced by $62 \%$. Women who consumed less than $800 \mathrm{mg}$ of calcium per day nearly had a 6 -fold increased risk of fractures than other female runners who consumed more than $1,500 \mathrm{mg}$ of calcium per day (Nieves et al., 2002).

Phosphorus is part of a number of compounds that are involved in energy metabolism of the body. Phosphate salts play an essential role in the use of glucose in aerobic efforts, affecting performance improvement. Through phosphorylation of these compounds, both anabolic and catabolic effects, which lead to the disintegration of molecules of ATP, from release of energy, also occur (Matwiejuk, 2009). Similarly to the studies of other authors 
(Burblis et al., 2014; Seidler, Gryza, 2006), our study also reported exceeding the recommendations in the supply of phosphorus in the DFR of those preparing for the marathon. It should be noted, however, that not only the content of phosphorus in the diet is important, but the molar ratio of phosphorus to calcium as well. The optimum ratio of calcium to phosphorus should be $1: 1$, and more preferably if it corresponds to the values observed in the bones, which are $1.5: 1$. In our study, the ratio of calcium to phosphorus in the diet was invalid, as it stood at $0.6: 1$ in both the men and women. The unfavourable ratio between calcium and phosphorus, lasting over a long period of time can contribute to weakening of the bone and early osteoporosis in adults (Burblis et al., 2014).

Magnesium is involved in many metabolic processes by acting as a cofactor and activator of many enzymes. It is a building component of bone and is involved in the metabolism of calcium. It affects the functioning of the muscles such as oxygen uptake and maintaining electrolyte balance. It determines the correct functioning of the neuromuscular system by keeping the electric gradient in the membranes of nerve and muscle cells. Magnesium deficiency intensifies the negative effects of prolonged physical exertion, such as oxidative stress. Magnesium also plays an important role in post-workout recovery (Christensen et al., 2005). Loss of magnesium is associated with excretion through sweat and urine. The demand for magnesium at EAR is 255-350 mg per day (Jarosz et al., 2012), but in athletes it may rise to about $480 \mathrm{mg}$ (Celejowa, 2008). The average intake of magnesium in DFR of the group of subjects examined fulfilled the recommendations for this nutrient. However, attention is drawn to the high percentage of diets of the studied men in which the supply of this mineral was insufficient. Similar results were also obtained by other researchers (Burblis et al. 2014; Onywera et al., 2004), who demonstrated that magnesium deficiency is a common problem in athletes and significantly affects physical fitness. Deficiency of this mineral can be relatively easily prevented by inclusion in the diet of products that are a good source, such as cereals, legumes, nuts, cocoa, dark chocolate and mineral water that contain more than $50 \mathrm{mg}$ per litre of this mineral.

Zinc is a part of over 300 enzymes. It is involved in the synthesis of nucleic acids and proteins, affects the utilization of glucose as well as insulin secretion. Furthermore it regulates the activities of the endocrine, immune and digestive systems. Because of the many functions of regulating, zinc is a mineral of significant importance during exercise and post-exercise recovery of the body (Christensen et al., 2005). Most of the zinc, about 60\%, is found in the muscle, and about $30 \%$ in the bones. Loss of zinc occurs through sweat and urine. The demand for zinc in adults at the EAR is 6.8-9.4 mg daily (Jarosz et al., 2012) and its deficiency occurs relatively rarely, due to the fact that zinc is present in many foods. Deuster et al. (1989) study demonstrated that long-distance runners did not obtain the recommended amount of zinc from their diets. Marginal dietary intake of this mineral affected more women than men, due to increased dietary restrictions in their diet. It should be noted, that the researchers compared their results to the higher recommended ranges of zinc amounting to 13-16 mg/day (Ziemlański, 2001). Horvath et al. (2000) showed that with the increase of the energy value of the diet and the percentage of energy from total fat, there was also an increase in zinc content in the diets of runners. In our study it was demonstrated that a relatively small percentage of the diets of women and men did not comply with the norm at the level of the EAR (Jarosz et al., 2012) for zinc (<90\%; $6.5 \%$ of women, $7.6 \%$ of men).

Copper is a vital component necessary for synthesis of haemoglobin and certain peptide hormones. Deficiencies of copper are also very rare because of its high prevalence in food (liver, whole grains, legumes, nuts). The demand for this mineral in adults is $2-2.5 \mathrm{mg}$. In our study, there was no shortage of copper in DFR, which seems to be consistent with the observations of other authors (Tong et al., 2012; Williams, 2005). 
In our study, the average intake of dietary sodium in both the men and women exceeded the reference values. Exceeding the norm for sodium is common among athletes which has also been documented in studies of other authors (Burblis et al., 2014; Pilis et al., 2014; Wierniuk, Włodarek, 2013). It should be noted, however, that in the case of physically active people, a significant amount of this element is excreted in sweat during exercise, in such amounts ranging from 400-650 mmol/I (Hew-Butler et al., 2006). It seems, therefore, that the demand for sodium among athletes is higher than in people who do not practise any sport because of the need to compensate for losses incurred during physical activity. During prolonged exercise, significant losses of sodium occur, causing progressive muscle weakness, impairment in maintaining acid-base balance of the body and the electric potential in the nerve cells. In accordance with the recommendations of the Scientific Committee on Food, during prolonged exercise, sodium supplementation is recommended, in the amount of 460-920 mg/l (Scientific Committee on Food Report 2001). However, in the study conducted by Hew-Butler et al. (2006) and Speedy et al. (2002), it was demonstrated in a group of people involved in a triathlon, that sodium supplementation is unnecessary, because the sodium content of the "Western diet" is sufficient to supplement its deficiencies, even during extreme physical exertion.

In our study, it was observed that the diets of $93.5 \%$ of women and $80.3 \%$ of men do not fulfil the norm for potassium. Potassium exhibits antagonist activity with respect to sodium and calcium, reducing the amount of extracellular fluid, and increases the permeability of cell membranes and muscle tension. Reduced concentration of this mineral in the blood causes rapid fatigue and muscle weakness. Pilis et al. (2014) and Kasprzak et al. (2006) also noted a deficiency of potassium in the DFR in athletes competing in long-distance and short-distance runs.

In our study, in the evaluation of the mineral content, supplementation was not taken into account. Because it is commonly believed that supplementation should provide nutritional support when the athlete is unable to meet the body's demands for specific components with a balanced diet. In many cases, assisting oneself with supplements has no effect on exercise performance, and often their improper use, particularly among amateurs, has adverse health effects (Aerenhouts, 2012; Rosenbloom et al., 2006; Williams, 2005). Knechtl et al. (2008) showed that taking vitamins and minerals (magnesium, zinc, iron, calcium) for 4 weeks prior to an ultra-marathon did not affect the achievement of better results compared to those not taking supplements.

A well-balanced diet that provides adequate amounts of vitamins and minerals is essential in order to achieve optimal performance in sports of an endurance nature. People training for a marathon should pay more attention to meeting the energy demand and consumption of high-quality products, rich in minerals. The needs of sportsmen as well as those of amateur sportsmen indicate the need for education in this field in order to improve their eating habits. A properly balanced diet is, in fact, part of supporting the achievement of satisfactory results in competition.

\section{Conclusions}

1. It was observed that a low supply of dietary minerals such as potassium, calcium and magnesium may be due to a lack of knowledge in the field of rational nutrition and points to the need for education in this area.

2. Amateurs training for long-distance running may be more vulnerable to shortages of minerals compared to those with low physical activity.

3. Due to the insufficient potassium content in the diets of both women and men preparing for a marathon, more attention should be paid to the intake of foods such as fresh and dried fruits, nuts, seeds, vegetables and potatoes. 


\section{References}

Aerenhouts, D., Deriemaeker, P., Hebbelinck, M., Clarys, P. (2012). Dietary intake vitamins and minerals in adolescent sprint athletes: a tree year follow-up study. J. Food Res., 1, 277-285.

Alaunyte, I., Stojceska, V., Plunkett, A. (2015). Iron and the female athlete: a review of dietary treatment methods for improving iron status and exercise performance. JISSN, 12, 38

Banfi, G., Lombardi, G., Colombini, A., Lippi, G. (2010). Bone metabolism markers in sports medicine. Sports Med., 8, 697-714.

Burblis, W., Pawluć, O., Obelewski, A., Szpakow, A. (2014). Sposób żywienia i stan odżywienia dziewcząt wyczynowo uprawiających piłkę nożna. Puls Uczelni, 8, 7-12.

Celejowa, I. (2008). Żywienie w sporcie. Warszawa: Wydawnictwo Lekarskie PZWL.

Christensen, D., Jakobsen, A., Friis, H. (2005). Vitamin and mineral intake of twelve adolescence male Kalenjin runners in Western Kenya. East Afr. Med. J., 82, 637-642.

Deuster, P.A., Day, B.A., Singh, S., Douglass, L., Moser-Veillon, P.B. (1989). Zinc status of highly trained women runners and untrained women. Am. J. Clin. Nutr., 49, 1295.

Dzięgiel, A., Lubowiecki-Vikuk, A. (2013). Imprezy biegowe jako specyficzny rodzaj wydarzeń sportowych. Zeszyty Naukowe. Turystyka i Rekreacja, 12, 119-135.

Figurska-Ciura, D., Bartnik, J., Bronkowska, M., Biernat, J. (2014). Jakościowa i ilościowa ocena wpływu edukacji żywieniowej na spożycie wybranych składników pokarmowych oraz ocena wiedzy żywieniowej młodych piłkarzy. Probl. Hig. Epidemiol., 95 471-476.

Gennari, C. (2001). Calcium and vitamin D nutrition and bone disease of the elderly. Pub. Health Nutr., 4, 547-559.

Hew-Butler, K., Sharwood, M., Collins, D., Speedy, T. (2006). Sodium supplementation is not required to maintain serum sodium concentrations during an Ironman triathlon. Br. J. Sports Med., 40, 255-259.

Horvath, P., Eagen, C., Ryer-Calvin, S., Pendergast, D. (2000). The effects of varying dietary fat on the nutrient intake in male and female runners. J. Am. Coll. Nutr., 19, 42-51.

Jarosz, M. (ed.) (2012). Normy żywienia dla populacji polskiej - nowelizacja. Warszawa: Instytut Żywności i Żywienia.

Kasprzak, Z., Biernacki, J., Nowak, A., Zieloński, J., Kusy, K., Rejewski, R. (2006). Assesment of intake essential nutrients, vitamins and minerals and selected indices of nutritional status in shorts-distance runners. Stud. Phys. Cult. Tourism., 13, 141-144.

Knechtle, B., Knechtle, P., Schulze, I., Kohler, G. (2008). Vitamins, minerals and race performance in ultra-endurance runners Deutschlandlauf. Asia Pac. Clin. Nutr., 17, 194-198.

Kunachowicz, H., Przygoda, B., Nadolna, I., Iwanow, K. (2005). Tabele składu i wartości odżywczej żywności. Warszawa: Wydawnictwo Lekarskie PZWL.

Lombardi, G., Lippi, G., Banfi, G. (2013). Iron Requirements and Iron Status of Athletes. In: R.J. Maughan (ed.), The Encyclopedia of Sports Medicine: An IOC Medical Commission Publication, Volume 19. John Wiley \& Sons Ltd, Chichester, UK. DOI: $10.1002 / 9781118692318 . c h 19$.

Lukaski, H. (2004). Vitamin and mineral status: effects on physical performance. Nutrition, 20, 632-644.

Matwiejuk, A. (2009). Składniki mineralne (makro- i mikroelementy) ich znaczenie w żywieniu sportowców. Roczniki Naukowe Wyższej Szkoły Wychowania Fizycznego i Turystyki w Białymstoku, 97, 97-99.

Maughan, R.J. (1999). Role of micronutrients in sport and physical activity. Brit. Med. Bulletin, 55, 683-690.

Merritt, J. (2013). Dietary Iron Intake and Knowledge of Iron Deficiency and Iron Deficiency Anemia Among Recreational Female Marathon Runners. Masters Theses, 1117.

Myburgh, K.H., Hutchins, J., Fataar, A.B, Hough, S.F., Noakes, T.D. (1999). Low bone density is an etiologic factor for stress fractures in athletes. Ann. Intern. Med., 113, 754-759.

Nieves, J.W., Melsop, K., Curtis, M., Kelsey, J.L., Bachrach, L.K., Greendale, G., Sowers, M.F., Sainani, K.L. (2002). Nutritional factors that influence change in bone density and stress fracture risk among young female cross-country runners. PMR, 2, 740-750.

Onywera, V.O., Kiplamai, F.K., Boit, M.K., Pitsiladis, Y.P. (2004). Food and macronutrient intake of elite Kenyan endurance runners. Int. J. Sport Nutr. Exerc. Metab., 6, 709-719.

Pilis, K., Michalski, C., Zych, M., Pilis, A., Jelonek, J., Kaczmarzyk, A., Pilis, W. (2014). A nutritional evaluation of dietary behavior in various professional sports. Rocz. Panstw. Zakl. Hig., 65, 227-234. 
Report of the Scientific Committee on Food on composition and specification of food intended to meet the expenditure of intense muscular effort, especially for sportsmen (2001). Available at: http:/lec.europa.eu/food/fs/sc/scf/out64_en.pdf.

Rosenbloom, Ch., Loucks, A., Ekblom, B. (2006). Nutritional and football special populations: the female player and the youth player. J Sports Sci., 24, 783-793.

Seidler, T., Gryza, M. (2006). Ocena spożycia składników odżywczych przez pływaków z województwa zachodniopomorskiego. Now. Lek., 75, 334-339.

Skrzypczak, T., Jarecka P., Fąk T. (2014). Imprezy rekreacyjno-sportowe jako współczesna forma budowania wizerunku Wrocławia. Zeszyty Naukowe Wyższej Szkoły Bankowej we Wrocławiu, 41, 303-310.

Speedy, D.B., Thompson, M.D., Rodgers, I., Collins, M., Sharwood, K. (2002). Oral Salt Supplementation During Ultradistance Exercise. Clin. J. Sport Med., 12, 279-284.

Szczepańska, B., Malczewska, J. (2003). Zawartość energii i wybranych składników mineralnych w całodziennych racjach pokarmowych stosowanych w żywieniu polskich sportowców. Żyw. Człow. Metab., 30, 538-543.

Szponar, L., Wolnicka, K., Rychlik, E. (2000). Album fotografii produktów i potraw. Warszawa: Instytut Żywności i Żywienia.

Tong, K., Lin, H., Lippi, G., Nie, J., Tian, Y. (2012). Serum oxidant and antioxidant status in adolescents undergoing professional endurance sports training. Oxid. Med. Cell. Longev. DOI: 10.1155/2012/741239.

Wierniuk, A., Włodarek, D. (2013). Estimation of energy and nutritional intake of young men practicing aerobic sports. Rocz. Panstw. Zakl. Hig., 64, 143-148.

Williams, M. (2005). Dietary supplements and sport performance: minerals. J. Int. Soc. Sports Nutr., 2, 43-49.

Włodarek, D., Kuźnia, A., Krusiec, J., Tymolewska-Niebuda, B. (2011). Ocena realizacji potrzeb energetycznych biegaczy długodystansowych oraz udział makroskładników w wartości energetycznej diety. Probl. Hig. Epidemiol., 92, 594-596.

Ziemlański, Ś. (2001). Normy żywienia człowieka. Fizjologiczne podstawy. Warszawa: Wydawnictwo Lekarskie PZWL.

Zimmermann, M. (2003). Vitamin and mineral suplementation and exercise performance. Sportmedizin und Sporttraumatologie, 51, 53-57.

Żbikowski, R., Lebiedzińska, A., Czaja, J. (2007). Współczesne trendy w sposobie żywienia lekkoatletów. Żyw. Człow. Metab., 34, 706-709.

Cite this artilcle aS: Salomon, A., Mandecka, A., Różańska, D., Konikowska, K., Kosendiak, A., Regulska-llow, B. (2017). Dietary Intake of Minerals in Diets of Adults Preparing for Marathon. Central European Journal of Sport Sciences and Medicine, 18 (2), 23-32. DOI: 10.18276/cej.2017.2-03. 